\title{
Identificação ideológica e voto para presidente (*)
}

\author{
Yan de Souza Carreirão \\ Universidade Federal de Santa Catarina
}

\begin{abstract}
Resumo
O trabalho testa a hipótese de Singer (1998) de que a "identidade ideológica" dos eleitores é um fator central na decisão de voto para presidente. A partir da análise dos dados de quatro surveys realizados entre 1989 e 1997, constata que há realmente uma correlação, de intensidade média moderada, entre o posicionamento numa escala esquerda-direita e o voto para presidente, para o conjunto do eleitorado brasileiro. A conclusão é a de que a proposta de Singer de inclusão de um componente de ordem ideológica parece pertinente num modelo que pretenda compreender o comportamento político de parcela significativa do eleitorado brasileiro, especialmente os eleitores de maior escolaridade
\end{abstract}

Palavras-chave: Comportamento eleitoral; Eleições presidenciais; Identificação ideoló-gica, Brasil

\begin{abstract}
In this study, Singer's (1998) hypothesis that the ideological identity of the voters is a central factor in the voting decision for President is tested. The findings, based on the data analysis of four surveys carried out between 1989 and 1997, shows that there really is a mild-intensity correlation between the positioning on a left-to-right scale and the vote for President, in the case of Brazilian voters. The conclusion is that Singer's proposal for the inclusion of a ideological component seems adequate within a model which aims to account for the political behavior of a large number of the Brazilian voters, especially the ones with high schooling.
\end{abstract}

Key words: Voting behavior, Brazilian Presidential elections, Ideological identity, Brazil

(*) Os dados utilizados neste trabalho foram obtidos durante a realização de curso de doutorado. Agradeço ao Departamento de Ciência Política da USP por financiar, com recursos do PROAP, a obtenção dos dados junto ao Cesop e à Capes pela bolsa do PICD concedida durante o período do curso. Agradeço pela gentileza e solicitude no fornecimento dos dados: ao Cesop - especialmente a seus coordenadores em diferentes momentos, Plínio Dentzien e Rachel Meneguello, e à pesquisadora Paula Cencig - e à Fundação Perseu Abramo, nas pessoas do coordenador do seu Núcleo de Opinião Pública, Gustavo Venturi e das pesquisadoras Rita Dias e Marisol Recaman. Agradeço ainda ao parecerista da revista pelas sugestões de modificações no texto. 


\section{0 voto por "identificação ideológica"}

O presente trabalho analisa a existência de relações entre a "ideologia" dos eleitores brasileiros e seu voto em eleições presidenciais. Partindo da noção de "identidade ideológica" proposta por Singer (1998), testa a tese deste autor de que aquela identidade é um fator central na decisão de voto para presidente.

É necessário, antes, fazer uma breve discussão sobre o conceito de "ideologia" e sua relação com o comportamento eleitoral. Encontramos na literatura internacional diversas concepções de "ideologia". Em uma primeira perspectiva, a partir de uma concepção mais exigente, um "voto ideológico" implicaria que o eleitor: i) formasse alguma opinião a respeito de vários temas (issues) políticos e que estas opiniões fossem razoavelmente coerentes entre si (do ponto de vista de um analista informado), ou seja, que o eleitor tivesse um "sistema de crenças estruturado"; ii) conhecesse as posições dos diferentes partidos e/ou candidatos quanto a estes temas; iii) escolhesse o partido (ou candidato) mais próximo de suas próprias posições. É aproximadamente esta a abordagem utilizada pelos primeiros trabalhos da chamada "Escola de Michigan" (especialmente Campbell et al, 1960 e Converse, 1964). Estes estudos indicavam que apenas uma pequena parcela dos eleitores seriam "ideológicos" (ou "quaseideológicos"), ou seja, tomavam suas decisões a partir da análise das posições dos partidos sobre questões políticas relevantes. ${ }^{1}$

Outras abordagens a respeito da ideologia e sua relação com o comportamento dos eleitores vão "relaxar" as exigências em relação ao grau de estruturação do "sistema de crenças" do eleitorado. Uma delas é a utilizada pelos recentes trabalhos de Singer (1993 e 1998), no Brasil, a partir da noção de "identificação ideológica".

Este autor vai partir da idéia, bem menos exigente, do "voto por imagem", de Sartori (1982), que não pressupõe que a maioria do eleitorado tenha um pensamento logicamente estruturado. Ao contrário, segundo esta perspectiva, a adesão a uma bandeira ideológica não requer alta sofisticação. ${ }^{2}$

Singer irá se apoiar, além de em Sartori, também no índice de "identificação" ou "sentimento" ideológico, proposto por Levitin e Miller (1979), para formular seu conceito de "identificação ideológica". Do ponto de vista empírico, utiliza a autolocalização dos eleitores no contínuo esquerda/direita (a partir de respostas de survey) para definir esta identificação.

Segundo o autor, $60 \%$ dos eleitores não sabem definir o que seja esquerda e direita, quando solicitados a fazê-lo. Mesmo assim, o eleitor poderia utilizar estes conceitos para orientar sua decisão de voto porque tratar-se-ia

\footnotetext{
${ }^{1}$ Para uma crítica a essa perspectiva, ver Fiorina (1981) e Wattenberg (1991).

${ }^{2}$ Segundo Sartori "a imagem partidária não é a mesma coisa que identificação partidária (...), é perfeitamente possível (...) várias pessoas identificarem-se com o mesmo partido embora tendo dele representações mentais muito diferentes (...). Uma imagem é, no meu entender, um vago pacote de políticas e programas condensado numa palavra ou frase, e por ela transmitido. 'Bom para os trabalhadores', ou ainda melhor, 'partido dos trabalhadores' é uma imagem (e não uma questão). Os rótulos liberal e conservador, progressista e reacionário, esquerda e direita, exemplificam tipicamente as imagens pelas quais os partidos procuram passar à frente uns dos outros" (Sartori, 1982, p. 360).
} 
"de um conhecimento intuitivo, de um sentimento do que significam as posições ideológicas. Esse sentimento permite ao eleitor colocar-se na escala em uma posição que está de acordo com suas inclinações, embora não as saiba verbalizar. Ea mesma intuição o conduz a situar os candidatos (e os partidos) nessa escala e votar coerentemente " (Singer, 1998, p.149).

Esta é a definição proposta pelo autor: "a identificação ideológica é a adesão a uma posição no contínuo esquerda-direita ou liberal-conservador que, mesmo sendo difusa, isto é, cognitivamente desestruturada, sinaliza uma orientação política geral do eleitor" (Singer, 1998, p. 43).

Neste trabalho o autor analisa dados das eleições de 1989 e 1994. A concepção mais geral é a de que o eleitor decide o voto a partir de predisposições de longo prazo e estímulos de curto prazo. Em relação a estes últimos, destaca o papel do Plano Real em 1994. Mas a ênfase principal em 1989 (especialmente no $2^{\circ}$ turno) e 1994 é na identidade ideológica, vista como uma predisposição de longo prazo e que teria sido um fator central da escolha eleitoral nestes dois pleitos.

Singer irá acrescentar uma série de dados buscando mostrar a estabilidade da identificação ideológica e sua relação com o voto no Brasil. Conclui, a respeito dos dados das duas eleições que analisou:

"por baixo das correntes superficiais determinadas pela conjuntura, o leito do rio manteve a orientação geral observada em 1989. O eleitorado continuou majoritariamente centrista e a direita superava em cerca de duas vezes os que se colocavam à esquerda. E tal como no pleito que elegeu Collor, a autolocalização no espectro direita-esquerda foi um forte preditor do voto, mesmo numa eleição em que a discussão econômica substituiu o debate ideológico como tema central. " (Singer, 1998, pp. 87/88).

Dada a importância da "identificação ideológica", um problema relevante seria o de descobrir qual visão do mundo estaria associada a essa identificação intuitiva. Embora classicamente as diferenças entre esquerda e direita estejam vinculadas à questão da mudança (ou conservação) e da igualdade (ou desigualdade baseada no mérito individual), o que o autor conclui para o Brasil é que o eleitorado em geral deseja mudanças igualitárias, não havendo quanto a isso diferenças substantivas, apenas um pouco mais de desejo de mudanças por parte do eleitorado de esquerda. Seria quanto à forma como essas mudanças devem ser alcançadas que se daria a diferença. Enquanto a esquerda estaria associada à idéia de mobilização social e de contestação da autoridade repressiva do Estado, a direita, em oposição, estaria associada à idéia de que as mudanças só ocorrerão mediante um reforço da autoridade do Estado. O conservadorismo dos eleitores que se colocam à direita não se expressaria em uma rejeição às mudanças, mas no apego à autoridade e à ordem. Quanto à intervenção estatal para adoção de medidas igualitárias, é o centro que tenderia a ter a posição menos estatizante. 


\section{Hipótese e base empírica do presente estudo}

A hipótese central que orienta este trabalho é a de que o significado do autoposicionamento dos eleitores numa escala esquerda-direita varia para eleitores com diferentes graus de escolaridade. Da mesma forma, a utilização de uma escala esquerda-direita para se situar politicamente e votar em acordo com ela, exige um grau de informação e uma capacidade cognitiva mínimos, que podem não estar presentes na maioria dos eleitores de menor escolaridade.

O trabalho aqui desenvolvido é o de testar a tese de Singer sobre a "identificação ideológica" do eleitorado brasileiro, mas utilizando a escolaridade como um fator de diferenciação do grau em que aquela "identificação" realmente ocorreria entre os eleitores e influenciaria seu voto. Isto será feito com base em quatro surveys: dois deles realizados em 1989/90 por convênio USP/Cedec/Datafolha; um realizado pelo Datafolha em 1993 e um survey realizado pelo Núcleo de Opinião Pública da Fundação Perseu Abramo em novembro de 1997, todos de âmbito nacional. ${ }^{3}$

\section{O significado do autoposicionamento dos eleitores em uma escala esquerda-direita}

Uma questão inicial trata do significado político das palavras "esquerda" e "direita", para os eleitores. As Tabelas 1 e 2 apresentam dados do survey nacional realizado pelo convênio USP/Cedec/Datafolha em setembro de 1989 com as principais respostas dos eleitores, segundo seu grau de escolaridade, à seguinte pergunta: "na sua opinião, qual é a diferença que há entre a esquerda e a direita na política? Noutras palavras, o que é para você ser de esquerda e ser de direita ?"

\footnotetext{
${ }^{3}$ Estes foram, dentre os surveys que utilizei em minha tese de doutorado (Carreirão, 2000), os únicos que continham questões relacionadas ao posicionamento dos eleitores frente à polarização esquerda-direita. No survey realizado em âmbito nacional pelo Datafolha em maio de 1993, embora não fosse pedido ao entrevistado para se posicionar numa escala esquerda-direita, havia uma pergunta em que o eleitor deveria dizer se preferia (genericamente) um candidato situado "mais à esquerda ou mais à direita". Embora não se trate, como nos demais surveys, do autoposicionamento dos eleitores numa escala, a resposta à questão não deixa de ser um indicador, de suas "preferências ideológicas". Quanto ao survey da Fundação Perseu Abramo, de novembro de 1997, a questão que solicitava aos eleitores que se autoposicionassem na escala esquerda-direita foi aplicada a uma sub-amostra de apenas 480 eleitores. Isso aumenta a margem de erro das inferências feitas a partir desta (sub-)amostra para o conjunto da população. De qualquer forma, os indícios resultantes da análise da relação entre autoposicionamento esquerda-direita dos eleitores e a intenção de voto reforçam as conclusões encontradas nos demais surveys.
} 
TABELA 1

Significado de "Esquerda", segundo escolaridade (Set/89) (\%)

\begin{tabular}{|c|c|c|c|c|}
\hline \multirow{2}{*}{ Significado de "Esquerda" } & \multirow{2}{*}{$\begin{array}{l}\text { Conjunto } \\
\text { Eleitores }\end{array}$} & \multicolumn{3}{|c|}{ Escolaridade } \\
\hline & & Até $1^{\circ} \mathrm{G}$. & $2^{\circ} \mathrm{Grau}$ & Superior \\
\hline 1) Não Sabe / Não Respondeu & 46 & 56 & 29 & 12 \\
\hline 2) Ë estar contra o governo & 19 & 12 & 34 & 39 \\
\hline 3) É o errado; o negativo & 10 & 12 & 7 & 1 \\
\hline 4) É o comunismo / socialismo & 8 & 4 & 10 & 25 \\
\hline $\begin{array}{l}\text { 5) É defender interesses dos pobres/ } \\
\text { trabalhadores }\end{array}$ & 4 & 3 & 6 & 10 \\
\hline 6) É a mais fraca; menos poderosa & 3 & 4 & 3 & 0,4 \\
\hline
\end{tabular}

Fonte: Cedec/USP/Datafolha - Setembro/89 (Universo: Brasil - $N=2083$ ).

Obs: As porcentagens foram calculadas sobre o número de eleitores em cada faixa de escolaridade.

$\mathrm{Na}$ coluna relativa ao conjunto dos eleitores, vemos que cerca de $46 \%$ dos entrevistados não responderam à questão sobre o que entendiam "ser de esquerda" em política. Se considerássemos como aceitáveis (a partir de certo uso "comum" das expressões e não a partir de critérios mais rigorosos, com base nos significados mais utilizados na Ciência Política) as respostas 2, 4 e 5 da tabela, teríamos, para o conjunto do eleitorado, pouco mais de $30 \%$ de eleitores com respostas que poderiam ser consideradas como mais ou menos "aceitáveis". ${ }^{4}$ Mais importante ainda é notar as diferenças entre as respostas dos eleitores segundo seu grau de escolaridade: há uma clara diminuição das proporções dos eleitores que não sabem responder à pergunta, à medida que passamos dos eleitores de menor escolaridade (56 \%), para os de escolaridade superior (12\%). Além disso, a proporção de respostas consideradas aqui como aceitáveis, cresce também substancialmente com a escolaridade: de $19 \%$ entre os eleitores com até $1^{\circ}$ Grau completo, a $74 \%$, entre os eleitores com nível superior.

A análise da Tabela 2 é muito semelhante em seus resultados à análise da tabela anterior. Evidentemente há diferenças nos conteúdos específicos das respostas às questões sobre o significado político das palavras "esquerda" e "direita". E, obviamente há algumas diferenças nas proporções dos eleitores que não souberam responder, ou responderam de forma mais ou menos adequada, em cada caso. Mas, a análise das duas tabelas leva, em termos substantivos, aos mesmos resultados.

\footnotetext{
${ }^{4}$ Como na experiência brasileira até o momento daquela pesquisa eram poucos os casos de governos municipais ou estaduais impor-tantes controlados por partidos de esquerda, e como este também não era o caso do governo federal, é impossível saber em que grau a resposta "é estar contra o governo" tem como referência esta experiência concreta ou é uma concepção mais genérica (em que, por exemplo, se a esquerda estivesse no poder, a direita, por estar fora dele, seria vista por este eleitorado como sendo a esquerda). De qualquer forma, frente à experiência concreta, a resposta não é considerada aqui como totalmente inadequada (como também em Singer, 1998).
} 
TABELA 2

Significado de "Direita", segundo escolaridade (Set./89) (\%)

\begin{tabular}{|l|c|c|c|c|}
\hline \multicolumn{1}{|c|}{ Significado de "Direita" } & Conjunto & \multicolumn{3}{c|}{ Escolaridade } \\
\cline { 3 - 5 } & Eleitores & Até $1^{\circ}$ G. & $2^{\circ}$ Grau & Superior \\
\hline 1) Não Sabe / Não Respondeu & 44 & 55 & 29 & 12 \\
\hline 2) Ser/ apoiar o governo & 19 & 11 & 34 & 40 \\
\hline 3) É o certo/ o melhor & 12 & 15 & 8 & 2 \\
\hline 4) É defender os interesses das elites & 5 & 3 & 8 & 17 \\
\hline 5) São os poderosos, os que têm poder & 5 & 4 & 6 & 5 \\
\hline 6) É defender os interesses do povo/ trabalhadores & 5 & 5 & 3 & 2 \\
\hline 7) É a liberdade econômica, política & 5 & 2 & 6 & 17 \\
\hline
\end{tabular}

Fonte: Cedec/USP/Datafolha - Setembro/89 (Universo: Brasil - $N=2083$ ).

Obs: As porcentagens foram calculadas sobre o número de eleitores em cada faixa de escolaridade.

As Tabelas Anexas 1 a 4 (apresentadas no final deste trabalho), relativas a questões idênticas para os surveys de maio/93 e novembro/97, mostram conclusões semelhantes: eleitores com baixa escolaridade dão respostas francamente inadeqüadas ou não sabem responder à questão em grau muito mais elevado do que eleitores com nível superior de escolaridade.

\section{O autoposicionamento dos eleitores na escala esquerda-direita}

As diferenças entre os eleitores, conforme seu grau de escolaridade não se reduzem apenas a um problema de verbalização da compreensão dos termos: a Tabela 3 mostra que a proporção dos eleitores que não se posicionam na escala (de 7 pontos), quando solicitados a fazê-lo, declina monotonicamente com a escolaridade, nos três surveys em que foi feita a pergunta sobre este autoposicionamento. Na média dos três surveys, $46 \%$ dos eleitores que não freqüentaram a escola não se posicionaram na escala, contra apenas $8 \%$ dos eleitores com nível superior.

\section{TABELA 3}

Proporção dos eleitores que não se posicionaram na escala esquerda-direita, segundo escolaridade (1989/90/97) (\%)

\begin{tabular}{|c|c|c|c|c|c|c|}
\hline \multirow[b]{2}{*}{ Pesquisa } & \multirow[b]{2}{*}{ Total } & \multicolumn{5}{|c|}{ Escolaridade } \\
\hline & & Não freq. Escola & $1^{\circ} \mathrm{Grau}$ Inc.. & $1^{\circ}$ Grau Comp. & $2^{\circ} \mathrm{Grau}$ & Superior \\
\hline Setembro/89 (*) & 22 & 42 & 24 & 18 & 16 & 8 \\
\hline Março/90 (*) & 19 & 46 & 23 & 16 & 12 & 6 \\
\hline Novembro/97 (**) & 25 & 51 & 27 & 22 & 21 & 9 \\
\hline
\end{tabular}

Fontes: Cedec/USP/Datafolha (Setembro/89 e Março/90) e Fundação Perseu Abramo - Núcleo de Opinião Pública (Universo: Brasil)

(*) Porcentagens na tabela correspondem às respostas "nenhuma / neutro / independente" e "não sabe / não respondeu", à pergunta sobre o autoposicionamento na escala esquerda-direita.

$\left.{ }^{* *}\right)$ Inclui entrevistados que responderam "Não Sei" ou não quiseram se posicionar, frente ao pedido do entrevistador para que eles mencionassem qual sua posição numa escala de 7 pontos (esquerda-direita). 
Quanto ao survey do Datafolha de maio de 1993, a questão formulada aos eleitores era: "quando se fala em política, muita gente separa os candidatos e os partidos entre os de esquerda e os de direita. Você prefere um candidato com uma posição política: 1 . Mais à esquerda ou, 2. Mais à direita? " (outras respostas ou "Não sei" eram anotadas, no caso das respostas dos eleitores não se enquadrarem naquelas opções apresentas ao entrevistado). Não há, portanto comparabilidade direta com aquela pergunta dos outros surveys, já que não se trata de como o eleitor define a si mesmo (como de esquerda, centro ou direita), mas de preferência por candidatos de esquerda ou direita. De toda forma, a análise dos dados pode ser útil para nosso estudo.

Como vemos na Tabela 4, a proporção de eleitores que responderam "não sei" à pergunta sobre preferência por candidatos de esquerda ou de direita foi um pouco menor (19\%) do que a média dos que não se autoposicionavam na escala esquerda. direita nos outros três surveys (22\%). Mas a tendência de declínio com a escolaridade é a mesma.

TABELA 4

Proporção de respostas "Não sei" à pergunta sobre preferência por candidatos de esquerda ou de direita, segundo escolaridade (Maio/93 (\%)

\begin{tabular}{|c|c|c|c|c|}
\hline \multirow{2}{*}{} & \multirow{2}{*}{ Total dos eleitores } & \multicolumn{3}{|c|}{ Escolaridade } \\
\cline { 3 - 5 } & 19 & Até $1^{\circ} \mathrm{Grau}$ & $2^{\circ} \mathrm{Grau}$ & Superior \\
\hline Não Sabe & $(23498)$ & 23 & 16 & 8 \\
\hline (N total) & $(1457)$ & (77.3) & (268) \\
\hline
\end{tabular}

Fonte: Datafolha / Maio/93 (Universo: Brasil - $N=2500$ ).

Obs: "Outras respostas" = "no centro"; "nenhum dos dois"; "tanto faz"; "depende do candidato".

Quanto à distribuição dos eleitores segundo seu autoposicionamento na escala, os dados são mostrados na Tabela 5. Há uma forte regularidade nos dados dos três surveys: a parcela maior do eleitorado se posiciona ao centro (35 a $41 \%$ ) e a seguir à direita (24 a $27 \%$ ); esta última parcela representa aproximadamente o dobro do eleitorado que se posicionava à esquerda (13 a 14 \%). Também considerando a distribuição dos posicionamentos dos eleitores de cada faixa de escolaridade, embora haja algumas variações, há uma certa regularidade: em todos os três surveys o posicionamento ao centro cresce com a escolaridade: o eleitorado com nível superior parece fortemente "centrista" (55 a 68\%, conforme o survey), ou posicionado à esquerda (19 a $24 \%$ ). O eleitorado de mais baixa escolaridade, por outro lado, parece majoritariamente "de direita" ou "centrista", com apenas 11 a $12 \%$ se posicionando à esquerda. 
Tabela 5

Autoposicionamento na escala esquerda-direita, segundo escolaridade (\%) (1989/90/97)

\begin{tabular}{|c|c|c|c|c|c|}
\hline Pesquisa & Posicionamento na escala $\left({ }^{*}\right)$ & Conjunto eleitores & Até $1^{\circ} \mathrm{Grau}$ & $2^{\circ} \mathrm{Grau}$ & Superior \\
\hline \multirow{5}{*}{$\begin{array}{c}\text { Setembro/ } \\
89\end{array}$} & Esquerda & 13 & 11 & 17 & 20 \\
\hline & Centro & 41 & 34 & 53 & 64 \\
\hline & Direita & 24 & 30 & 14 & 8 \\
\hline & Não Sabe & 22 & 26 & 16 & 8 \\
\hline & $(\mathrm{N})$ & (1984) & $(1352)$ & $(407)$ & $(225)$ \\
\hline \multirow{5}{*}{ Março/90 } & Esquerda & 14 & 11 & 17 & 19 \\
\hline & Centro & 41 & 31 & 52 & 68 \\
\hline & Direita & 27 & 34 & 19 & 8 \\
\hline & Não Sabe & 19 & 24 & 12 & 6 \\
\hline & $(\mathrm{N})$ & $(2438)$ & $(1531)$ & $(585)$ & $(322)$ \\
\hline \multirow{5}{*}{$\begin{array}{c}\text { Novembro/ } \\
97\end{array}$} & Esquerda & 13 & 12 & 16 & 12 \\
\hline & Centro & 35 & 27 & 46 & 55 \\
\hline & Direita & 27 & 31 & 16 & 24 \\
\hline & Não Sabe & 25 & 29 & 21 & 9 \\
\hline & $(\mathrm{N})\left(^{* *}\right)$ & $(480)$ & (307) & (122) & (51) \\
\hline
\end{tabular}

Fontes: Cedec/USP/Datafolha (Setembro/89 e Março/90) e Fundação Perseu Abramo - Núcleo de Opinião Pública (Universo: Brasil). $\left(^{*}\right)$ O "posicionamento ideológico" dos eleitores foi operacionalizado a partir da seguinte recodificação da escala original de 7 pontos: esquerda $=$ posições 1 e 2 ; centro = posições 3 a 5 ; direita $=$ posições 6 e 7. A forma de operacionalizar esta variável foi a mesma usada em Singer (1998: 81); (**) O survey foi aplicado a 2670 eleitores brasileiros, mas a pergunta sobre posicionamento E/D foi feita a apenas 480 deles. Os eleitores sem escolaridade eram em número muito baixo e por isso foram agregados aos com até $1^{\circ} \mathrm{Grau}$.

Quanto ao survey do Datafolha de maio de 1993, como já foi visto, a questão formulada era diferente das questões dos demais surveys. A Tabela 6 mostra os dados relativos às preferências dos eleitores por candidatos mais à esquerda ou mais à direita.

Aqui, uma dificuldade é a inexistência de uma opção de resposta (explícita) correspondente a um candidato de centro. Apesar de $13 \%$ dos entrevistados apontarem - além das duas opções de resposta (esquerda ou direita) explícitas na pergunta - outras respostas à questão (entre elas a de preferência por candidato de centro), certamente a não explicitação dessa opção no enunciado da pergunta distorce qualquer possibilidade de comparação direta com a questão do autoposicionamento do eleitor na escala esquerda-direita.

Mas, ainda assim, a análise desses dados pode nos dar pistas interessantes, já que, pelo menos para os eleitores para os quais as categorias esquerda e direita têm um significado político, estas respostas podem representar um indicador de suas "preferências ideológicas". 
TABELA 6

Preferência por candidatos à esq. ou à direita, segundo escolaridade dos eleitores (Maio/93)

\begin{tabular}{|c|c|c|c|c|}
\hline \multirow{2}{*}{$\begin{array}{c}\text { Preferência por } \\
\text { candidatos }\end{array}$} & \multirow{2}{*}{$\begin{array}{c}\text { Total dos } \\
\text { eleitores }\end{array}$} & \multicolumn{3}{|c|}{ Escolaridade } \\
\cline { 3 - 5 } & & Até $1^{\circ}$ Grau & $2^{\circ}$ Grau & Superior \\
\hline Esquerda & 24 & 16 & 33 & 40 \\
\hline Direita & 45 & 52 & 37 & 30 \\
\hline Outras Respostas & 13 & 8 & 15 & 23 \\
\hline Não Sabe & 19 & 23 & 16 & $(268)$ \\
\hline$(\mathrm{N})$ & $(2498)$ & $(1457)$ & $(773)$ & $($ ) \\
\hline
\end{tabular}

Fonte: Datafolha / Maio/93 (Univ.: Brasil - $N$ = 2500). Obs: "Outras respostas" = "no centro"; "nenhum dos dois"; "tanto faz"; "depende do candidato".

No conjunto de eleitores, a preferência por candidatos à direita (45\%) é quase o dobro da preferência por candidatos à esquerda (24\%). Há, no entanto, diferenças significativas entre os eleitores de acordo com sua escolaridade: entre aqueles com até $1^{\circ} \mathrm{Grau}$, a preferência pela direita (em relação à esquerda) é ainda maior (52\% e $16 \%$, respectivamente); à medida que cresce a escolaridade dos eleitores esta tendência vai se invertendo, de tal forma que nos eleitores com nível superior a preferência pela esquerda (40 \%) supera a preferência pela direita (30 \%). No conjunto dos entrevistados cerca de $13 \%$ se enquadram na categoria "outras respostas", que incluem: "depende do candidato"; "qualquer um / tanto faz "; "no centro"; "nenhum dos dois". Este percentual cresce também com a escolaridade (de $8 \%$ a $23 \%$ ). Como já foi dito, não é possível uma comparação rigorosa com os dados de autoposicionamento na escala esquerda-direita existente em outros surveys. De qualquer forma, a tendência de que uma preferência pela direita seja aproximadamente o dobro de uma preferência pela esquerda é semelhante à encontrada naqueles dados.

Há, porém, alguns problemas para interpretar o significado dessas regularidades: como já foi mostrado, o significado atribuído aos termos esquerda e direita varia muito com a escolaridade; além disso, a relação entre o posicionamento dos eleitores na escala e o voto (e suas opiniões políticas e preferências partidárias) também varia muito, segundo o grau de escolaridade dos eleitores. Dessa forma, é possível pensar que essa regularidade se deva em parte a efeitos de agregação que escondem mudanças individuais e em parte a uma continuidade efetiva no plano individual. Neste último caso, porém, ainda pode haver pelo menos duas possibilidades: um grupo de eleitores (principalmente entre os de alta escolaridade) para quem a escala tem algum significado político e o posicionamento tem relação com o voto, e um grupo (especialmente entre os eleitores de baixa escolaridade) que, por interpretar equivocadamente as noções de esquerda e direita, poderia se posicionar sempre no mesmo setor da escala, mas esse posicionamento não teria relação com o voto. Os dados aqui disponíveis, embora não permitam formular uma interpretação clara do significado daquela continuidade da distribuição dos eleitores na escala esquerda-direita ao longo do período estudado, parecem sugerir que pode se tratar de uma mistura das diversas possibilidades apontadas acima. 


\section{5. "Posicionamento ideológico" e voto}

A Tabela 7 apresenta os coeficientes gama de correlação entre o "posicionamento ideológico" dos eleitores e sua intenção de voto, para cada faixa de escolaridade, para os surveys aqui disponíveis. ${ }^{5}$

Iniciarei pela análise dos dados referentes ao "conjunto de eleitores". O grau de correlação entre o posicionamento dos eleitores na escala e seu voto variou, de baixo $(0,26)$ a substancial $(0,53)$, nos quatro surveys analisados. ${ }^{6}$ Mas é importante considerar que estes coeficientes foram calculados apenas para aqueles eleitores que simultaneamente se autoposicionavam na escala e pretendiam votar em algum candidato. Assim, por exemplo, o coeficiente de 0,30 no primeiro survey foi calculado apenas para $70 \%$ do conjunto da amostra ${ }^{7}$, já que os demais $30 \%$ não se posicionavam na escala esquerda-direita ou , mesmo se posicionando, pretendiam votar em branco ou nulo. ${ }^{8}$

\footnotetext{
${ }^{5}$ Será chamado genericamente de "posicionamento ideológico" seja o autoposicionamento dos eleitores numa escala esquerdadireita, seja a resposta, no survey de maio/93, à resposta sobre a preferência por votar num candidato à esquerda ou à direita. Este "posicionamento" foi assim operacionalizado: no survey de maio/93, além das respostas "esquerda" e "direita", foi estabelecida como uma categoria intermediária as "outras respostas" ("no centro"; "nenhum dos dois"; "tanto faz"). Nos demais surveys, em que a pergunta solicitava o autoposicionamento do eleitor numa escala de 7 pontos, foi feita a operacionalização indicada na Tabela 5. Quanto à variável intenção de voto: nas duas pesquisas USP/Cedec/Datafolha, relativas ao $1^{\circ}$ turno da eleição de 1989: esquerda = Lula (PT), Leonel Brizola (PDT) e RobertoFreire (PCB); centro = Mário Covas (PSDB), Ulysses Guimarães (PMDB), Guilherme Afif (PL) e Affonso Camargo (PTB); direita = Fernando Collor (PRN); Paulo Maluf (PDS) e Aureliano Chaves (PFL). Essa classificação segue a dos partidos a que os candidatos pertencem; esta última segue a classificação feita por Singer (1998: 67), com base em pesquisa do IUPERJ e em classificação da FIESP. Trabalhos como os de Kinzo (1990) e Figueiredo e Limongi (1999) apontam para classificações muito semelhantes a esta. Operacionalizando as duas variáveis de forma mais desagregada (com 5 ou 7 posições), chegamos a coeficientes de correlação um pouco mais baixos, mas a seqüência de crescimento dos coeficientes é a mesma: dos eleitores de mais baixa escolaridade para os de mais alta. Quanto ao $2^{\circ}$ turno, a intenção de voto foi operacionalizada assim: 1 = Lula; $2=$ branco/nulo; $3=$ Collor. Isso foi feito de forma a poder utilizar o coeficiente gama de correlação (que é adeqüado para variáveis ordinais), mantendo a comparabilidade com as demais correlações. (A pesquisa de setembro de 1989 não fazia pergunta sobre intenção de voto no segundo turno, por isso não foi incluída na análise). No survey de maio de 1993 a variável intenção de voto foi assim operacionalizada: Esquerda = Lula + Brizola; Centro = Tasso Jereissati + Luiz A.Fleury + Hélio Garcia; Direita = Antônio Carlos Magalhães + Maluf + Joaquim Francisco. Mesmo se considerássemos o candidato Hélio Garcia à direita, isso praticamente não alteraria os resultados, pois ele tinha então pouco mais de $1 \%$ das intenções de voto. No survey de novembro de 1997 a variável intenção de voto foi codificada, da seguinte forma (seguindo o critério de posicionamento do partido ao qual estava vinculado cada candidato): esquerda = Lula e Ciro Gomes; centro = FHC e Sarney; direita = Enéas. Outras formas de operacionalizar as duas variáveis, neste survey, levam, em geral, a coeficientes de mesma magnitude, embora haja algumas variações (Ver Tabela Anexa 5).

${ }^{6} \mathrm{O}$ coeficiente gama varia de $-1 \mathrm{a}+1$. Uma forma muito utilizada de categorizar a força da correlação é a seguinte: coeficientes de até 0,09 (positivos ou negativos) correspondem a uma associação desprezível entre as variáveis; de 0,10 a 0,29 , uma associação baixa; de 0,30 a 0,49, uma associação moderada; de 0,50 a 0,69, uma associação substancial e acima de 0,70, uma associação forte (Davis,1976).

${ }^{7}$ Este percentual foi calculado dividindo o número dos eleitores que ao mesmo tempo se autoposicionavam e pretendiam votar em algum candidato, pelo total dos eleitores, descontados aqueles que responderam "Não Sei" à pergunta sobre intenção de voto. ${ }^{8} \mathrm{Se}$ os eleitores não se posicionavam na escala, é evidente que o autoposicionamento não pode ser considerado como influenciando o voto; se os eleitores se posicionavam na escala, mas pretendiam votar nulo ou em branco, também parece que seu posicionamento não foi suficiente para que sua escolha recaísse sobre um candidato com o mesmo "posicionamento ideológico" que o seu.
} 
TABELA 7

Correlação (Gama) entre intenção de voto e posicionamento ideológico, segundo escolaridade (1º Turno/1989)

\begin{tabular}{|c|c|c|c|c|c|c|}
\hline \multirow[b]{2}{*}{$\begin{array}{l}\text { Survey/ } \\
\text { Eleição }\end{array}$} & \multirow[b]{2}{*}{$\begin{array}{l}\text { Conjunto } \\
\text { eleitores }\end{array}$} & \multicolumn{5}{|c|}{ Escolaridade } \\
\hline & & $\begin{array}{c}\text { Não } \\
\text { freqüentou } \\
\text { escola }\end{array}$ & $\begin{array}{c}\text { Até } 1^{\circ} \\
\text { Grau } \\
\text { incompl. }\end{array}$ & $\begin{array}{l}1^{\circ} \mathrm{Grau} \\
\text { completo }\end{array}$ & $2^{\circ} \mathrm{Grau}$ & Superior \\
\hline $\begin{array}{l}\text { Setembro } 1989 / \\
1^{\circ} \text { Turno/89 }\end{array}$ & $0,30 * *$ & $\cdot 0,13$ & 0,14 & 0,14 & $0,43 * *$ & $0,65^{* *}$ \\
\hline$\frac{(\% \text { Eleitores) (1) }}{\text { Marco 1990/ }}$ & $\frac{(70 \%)}{0,45^{* *}}$ & $\frac{(64 \%)}{.0,13}$ & $\frac{(71 \%)}{0.29 * *}$ & $\frac{(72 \%)}{0,48 * *}$ & $\frac{(18 \%)}{0,53^{* * *}}$ & $\frac{(85 \%)}{0.82^{* * *}}$ \\
\hline $\begin{array}{l}1^{\circ} \text { Turno/89 } \\
\text { (\% Eleitores) (1) }\end{array}$ & $(79 \%)$ & (59\%) & $(75 \%)$ & $(81 \%)$ & (84\%) & $(93 \%)$ \\
\hline $\begin{array}{c}\text { Março 1990/ } \\
2^{\circ} \text { Turno/89 } \\
\text { (\% Eleitores) (1) }\end{array}$ & $\begin{array}{l}0,53^{* *} \\
(80 \%)\end{array}$ & $\begin{array}{l}-0,34 \\
(60 \%)\end{array}$ & $\begin{array}{l}0,35^{* *} \\
(75 \%)\end{array}$ & $\begin{array}{l}0,49 * * \\
(81 \%)\end{array}$ & $\begin{array}{l}0,66 * * \\
(85 \%)\end{array}$ & $\begin{array}{l}0,66^{* *} \\
(94 \%)\end{array}$ \\
\hline $\begin{array}{c}\text { Maio 1993/ } \\
\text { (\% Eleitores) (1) }\end{array}$ & $\begin{array}{l}0,39 * * \\
(69 \%)\end{array}$ & ND & ND & $\begin{array}{l}0,30 * * \\
(66 \%)\end{array}$ & $\begin{array}{l}0,42^{* * *} \\
(71 \%)\end{array}$ & $\begin{array}{l}0,68^{* *} \\
(76 \%)\end{array}$ \\
\hline $\begin{array}{l}\text { Novembro } 1997 \\
\text { (\% Eleitores) (1) }\end{array}$ & $\begin{array}{l}0,26 * * \\
(63 \%)\end{array}$ & (a) & $\begin{array}{c}0,20 \\
(61 \%)\end{array}$ & $\begin{array}{l}0,51^{* *} \\
(67 \%)\end{array}$ & $\begin{array}{c}0,18 \\
(62 \%)\end{array}$ & $\begin{array}{l}0,77^{* *} \\
(74 \%)\end{array}$ \\
\hline
\end{tabular}

Fontes: Cedec/USP/Datafolha (Set/89 - Brasil e Março/90 - Brasil); Datafolha / Maio/93 (Universo: Brasil); Fundação Perseu Abramo - Núcleo de Opinião Pública (Universo: Brasil); $\left(^{*}\right)$ coef. significativo nível 0,05; $\left(^{* *}\right)$ coef. significativo nível 0,01; demais coef. não signif. estatisticamente. (1) São indicadas as porcentagens de eleitores, em cada categoria, a partir das quais foram feitos os cálculos dos coeficientes de correlação. Isso nos dá uma indicação das proporções de missing cases, em cada análise; $N D=$ Não há dados (a questão sobre escolaridade não incluía as opções). (a) A pergunta sobre autoposicionamento esquerda-direita foi feita a apenas 480 eleitores. Os eleitores sem escolaridade eram em número muito baixo (14) e por isso foram agregados aos com até $1^{\circ} \mathrm{Grau}$ incompleto.

Há variações significativas entre os diversos surveys: assim, para o $1^{\circ}$ turno da eleição de 1989, as correlações entre "posicionamento ideológico" e voto apresentaram força moderada $\left(0,30\right.$ e 0,45). ${ }^{9}$ Quanto ao $2{ }^{\circ}$ turno, os coeficientes são maiores do que os coeficientes encontrados para o primeiro turno da eleição, para todas as faixas de eleitores. A única exceção é entre os eleitores com nível superior, em que um dos coeficientes para o primeiro turno foi maior do que o encontrado para o segundo. Uma explicação possível é a de que numa eleição muito polarizada ideologicamente entre apenas dois candidatos (como no $2^{\circ}$ turno), a "localização" dos candidatos no "espaço" esquerda-direita, pelos eleitores, é mais fácil do que numa eleição entre muitos candidatos de todos os matizes ideológicos (como no $1^{\circ}$ turno).

No survey de maio de 1993, a correlação entre as respostas às duas questões, para o conjunto dos eleitores, é de grau mediano (coeficiente de 0,39). ${ }^{10}$

\footnotetext{
${ }^{9}$ Os coeficientes no segundo são maiores do que no primeiro survey em todas as faixas de escolaridade. Isso poderia se dever, como observou Singer (1998), ao fato da maior polarização ideológica ter se dado no $2^{\circ}$ turno da eleição, entre Collor e Lula. Como o segundo survey foi realizado após o segundo turno, ele teria captado uma visão dos eleitores sobre o conflito político mais balizada por termos como "direita" e "esquerda" do que a visão captada no primeiro survey.

${ }^{10}$ De forma a realizar a análise de correlação, foram desconsiderados nesta análise, os eleitores que responderam "não sei" à questão sobre preferência por candidatos mais à esquerda ou mais à direita e os que responderam que pretendiam votar em branco, ou nulo, ou não sabiam em quem votar, na pergunta sobre intenção de voto. A análise se restringe, portanto, apenas aos $69 \%$ dos eleitores que simultaneamente escolheram algum candidato e deram alguma resposta à questão mais genérica sobre a posição política (do candidato) em que preferiam votar. Os eleitores que deram "outras respostas" a esta última questão foram considerados uma categoria intermediária entre os que reponderam preferir votar "mais à esquerda" ou "mais à direita".
} 
Quanto ao survey de novembro de 1997, o grau de correlação entre o posicionamento dos eleitores na escala esquerda-direita e seu voto é baixo $(0,26)$, mas estatisticamente significativo.De qualquer forma, do ponto de vista que aqui mais nos interessa, com apenas uma exceção (no survey de 1997) há uma seqüência bem clara nos coeficientes de correlação: eles crescem à medida que cresce a escolaridade dos eleitores. Entre os eleitores sem escolaridade (onde havia dados suficientes para esta faixa de escolaridade, ou seja, nos dois surveys relativos à eleição presidencial de 1989) as correlações entre "posicionamento ideológico" do eleitor e seu voto são negativas (devido à tendência ao voto em candidatos à direita ser maior entre os eleitores que se autoposicionavam à esquerda na escala, do que entre os que se posicionavam à direita); entre os eleitores com até $1^{\circ}$ Grau incompleto as correlações são positivas, mas baixas, com exceção de uma, moderada. Já entre os demais eleitores, com algumas exceções, a tendência é a seguinte: eleitores com $1^{\circ}$ Grau completo: correlações moderadas; eleitores com $2^{\circ}$ Grau: correlações entre moderadas a substanciais; eleitores de nível superior: correlações substanciais a fortes.

Se isso mostra que há diferenças importantes entre os eleitores, segundo seu grau de escolaridade, não deve obscurecer o fato de que, excetuando-se os eleitores sem qualquer escolaridade, todos os demais apresentaram um padrão de voto associado (no sentido esperado), em maior ou menor grau, ao seu autoposicionamento na escala esquerda-direita.

\section{6. "Posicionamento ideológico" e preferência partidária}

Uma outra questão relevante é saber qual a relação entre o autoposicionamento do eleitor na escala esquerda-direita e o partido que ele prefere.

TABELA 8 -Correlação (Gama) entre pref. partidária e posicionamento ideológico, segundo escolaridade (1989/90)

\begin{tabular}{|c|c|c|c|c|c|c|}
\hline & \multirow{2}{*}{ Pesquisa } & \multicolumn{5}{|c|}{ Escolaridade } \\
\cline { 3 - 7 } & \multirow{2}{*}{$\begin{array}{c}\text { "Total” } \\
\text { de }\end{array}$} & $\begin{array}{c}\text { Não } \\
\text { freqüentou } \\
\text { escola }\end{array}$ & $\begin{array}{c}\text { Até } 1^{\circ} \\
\text { Grau inc.. }\end{array}$ & $\begin{array}{c}1^{\circ} \text { Grau } \\
\text { comp. }\end{array}$ & $2^{\circ}$ Grau & Superior \\
\hline Set. 1989 (\% dos eleitores com & $0,30^{* * *}$ & $-0,30$ & 0,06 & $0,33^{*}$ & $0,43^{* * *}$ & $0,71^{* * *}$ \\
preferência partidária) (1) & $(80 \%)$ & $(62 \%)$ & $(79 \%)$ & $(80 \%)$ & $(82 \%)$ & $(95 \%)$ \\
\hline Março 1990 (\% dos eleitores com & $0,46^{* *}$ & $-0,39$ & $0,28^{* *}$ & $0,25^{*}$ & $0,52^{* *}$ & $0,79^{* *}$ \\
preferência partidária) (1) & $(88 \%)$ & $(78 \%)$ & $(84 \%)$ & $(89 \%)$ & $(90 \%)$ & $(99 \%)$ \\
\hline Maio 1993 (\% dos eleitores com & $0,54^{* *}$ & ND & ND & $0,42^{* *}$ & $0,57^{* *}$ & $0,73^{* *}$ \\
preferência partidária) (1) & $(84 \%)$ & & & $(80 \%)$ & $(87 \%)$ & $(93 \%)$ \\
\hline Novembro 1997 (\% dos eleitores & $038^{* *}$ & $(a)$ & $0,36^{*}$ & 0,18 & $0,47^{*}$ & $0,82^{* * *}$ \\
com preferência partidária) (1) & $(83 \%)$ & & $(83 \%)$ & $(77 \%)$ & $(91 \%)$ & $(99 \%)$ \\
\hline
\end{tabular}

Fontes: Cedec/USP/Datafolha (Set./89 - Brasil e Mar./90 - Brasil); Datafolha / Maio/93 (Universo: Brasil ; N = 2500); Fundação Perseu Abramo - Núcleo de Opinião Pública - Nov.197 (Universo: Brasil). ( ${ }^{*}$ ) coef. significativo nível 0,05; $\left.{ }^{* *}\right)$ coef. signif. nível 0,01; demais coef. não signif. estatisticamente.(1)São indicadas as porcentagens de eleitores a partir das quais foram feitos os cálculos dos coef. de correlação, calculadas em relação não ao conj. de eleitores, mas aos eleitores com alguma pref. partidária, em cada categoria; ND = Não há dados (a questão sobre escolaridade não incluía as opções). (a) A pergunta sobre autopos. esquerda-direita foi feita a apenas 480 eleitores. Os eleitores sem escolaridade eram em número muito baixo (14) e por isso foram agregados aos com até $1^{\circ} \mathrm{Grau}$ incompleto. 
A Tabela 8 resume os coeficientes de correlação entre autoposicionamento do eleitor na escala esquerda-direita e sua preferência partidária, controlado por sua escolaridade, para os surveys aqui disponíveis. ${ }^{11}$

Como se vê, considerando apenas o conjunto dos eleitores que manifestaram preferência partidária e algum "posicionamento ideológico"12, as correlações são de força moderada a substancial (com coeficientes semelhantes aos encontrados para a correlação entre autoposicionamento e voto).

Além disso, as correlações crescem com a escolaridade dos eleitores: entre aqueles sem escolaridade as correlações são negativas; entre aqueles com até $1^{\circ} \mathrm{Grau}$ incompleto os coeficientes são baixos, chegando a valores altos apenas nas faixas de maior escolaridade. As diferenças entre os eleitores, segundo sua escolaridade, devem ser percebidas não só através dos coeficientes de correlação: para os eleitores com até $1^{\circ} \mathrm{Grau}$ incompleto, além das correlações serem menores, os coeficientes $(0,06$ a 0,36) foram calculados entre 79 a $84 \%$ dos eleitores desta faixa que manifestaram preferência partidária. Já entre os eleitores com nível superior, as altas correlações encontradas $(0,71$ a 0,82) são válidas para praticamente todos os eleitores que manifestaram alguma preferência partidária, já que 93 a $99 \%$ deles conseguiam se posicionar na escala esquerda-direita (embora os eleitores com alguma preferência partidária representem uma minoria mesmo nesta faixa de escolaridade).

\section{Posicionamento na escala esquerda-direita e opinióes políticas}

Uma questão relevante é saber se o autoposicionamento do eleitor na escala esquerda-direita está associado a alguma(s) de suas opiniões políticas específicas. Já foi visto que Singer (1998) identificou como elemento diferenciador da identidade ideológica dos eleitores uma certa polarização em relação à forma como deveriam ocorrer as mudanças sociais: enquanto aqueles de esquerda associariam essas mudanças à idéia de mobilização popular, para aqueles de direita essas mudanças deveriam ocorrer mediante um reforço da autoridade do Estado.

O objetivo da análise a seguir é testar se o "posicionamento ideológico" associase com a mesma intensidade com as opiniões políticas, para eleitores de diferentes graus de escolaridade e, além disso, a quais conteúdos substantivos associam-se os posicionamentos à esquerda e à direita, entre eleitores com diferentes graus de escolaridade.

As Tabelas 9, 10 e 11 mostram as correlações entre o autoposicionamento dos

\footnotetext{
${ }^{11}$ As variáveis autoposicionamento na escala e preferência partidária foram operacionalizadas, com 3 posições cada (esquerda; centro; direita), conforme Nota 5 (substituindo os candidatos por seus partidos, no caso de preferência partidária). Os eleitores que preferiam "outros partidos", bem como os sem preferência partidária, foram considerados como missing cases.

${ }^{12}$ Vale notar que nos surveys em estudo, como em muitos outros surveys realizados ao longo do período em estudo (1989/98), os eleitores que manifestaram preferência por algum partido representavam em torno de 40 a $50 \%$ do eleitorado nacional. Dentre estes eleitores (com preferência partidária), em média 84 \% se posicionavam na escala esquerda-direita.
} 
eleitores na escala esquerda-direita e suas opiniões a respeito de uma série de temas (democracia x ditadura; participação popular nas decisões; igualitarismo sócioeconômico; grau de intervenção do estado na economia e/ou nas políticas sociais), nos surveys de setembro de 1989, março de 1990 e novembro de $1997 .{ }^{13}$

\section{Tabela 9}

\section{Correlação (Gama) entre opiniões políticas e posicionamento na escala esquerda-direita,} segundo escolaridade (Setembro/89)

\begin{tabular}{|c|c|c|c|c|c|}
\hline Questão (1) & $\begin{array}{l}\text { Conjunto } \\
\text { Eleitores }\end{array}$ & $\begin{array}{l}\text { Até } 1^{\circ} \mathrm{G} \text {. } \\
\text { Incompl. }\end{array}$ & $\begin{array}{l}1^{\circ} \mathrm{Grau} \\
\text { Completo }\end{array}$ & $2^{\circ} \mathrm{Grau}$ & Superior \\
\hline Democracia $\times$ ditadura & 0,09 & $.0,01$ & 0,04 & 0,16 & 0,22 \\
\hline Minoria deve influir nas decisões? & $.0,11^{* *}$ & $.0,01$ & .0 .09 & $.0,06$ & $.0,25$ \\
\hline Líder forte $\mathrm{x}$ participação popular & 0,08 & 0,06 & $.0,03$ & 0,08 & $0,25^{*}$ \\
\hline Proibição de greves & $0,25^{* *}$ & $0,18^{* * *}$ & $.0,02$ & $0,29 * *$ & $0,40 * *$ \\
\hline Intervenção em sindicatos & $0,24 * *$ & $0,14^{*}$ & $.0,01$ & $0,37^{* * *}$ & $0,54 * *$ \\
\hline Proibição de partidos & $0,25 * *$ & $0,13^{*}$ & 0,19 & 020 & $0,40^{*}$ \\
\hline Censura a meios de comunicação & $0,12^{* *}$ & 0,11 & $.0,34$ & 0,11 & $0,30^{*}$ \\
\hline Fechamento do Congresso & 0,02 & 0,03 & $.0,12$ & $.0,02$ & 0,06 \\
\hline $\begin{array}{l}\text { Participação do Estado na economia e } \\
\text { serviços sociais }\end{array}$ & $0,12^{* *}$ & 0,12 & 0,15 & 0,00 & $0,28^{*}$ \\
\hline $\begin{array}{l}\text { Democracia é perigosa porque pode } \\
\text { gerar desordem }\end{array}$ & $0,15^{* *}$ & 0,00 & $.0,01$ & 0,15 & $0,51^{* * *}$ \\
\hline Mudanças só com revolução ou violência & 0,06 & 0,05 & 0,07 & $0,25 *$ & 0,18 \\
\hline Justiça $\times$ miséria e desigualdade & $.0,06$ & 0,04 & 0,06 & $.0,16$ & 0,06 \\
\hline Povo deve opinar nas leis? & $0,12^{* *}$ & 0,04 & 0,17 & $.0,06$ & 0,17 \\
\hline Igualdade/distribuição da riqueza & 0,02 & 0,16 & $.0,06$ & 0,16 & 0,15 \\
\hline Volta dos militares ao poder & $0,30 * *$ & $0,22 * *$ & 0,13 & $0,22^{*}$ & 0,05 \\
\hline Sempre haverá ricos e pobres & 0,06 & $.0,17$ & 0,10 & 0,09 & $0,48 * *$ \\
\hline $\begin{array}{l}\text { No capitalismo quem se esforça pode } \\
\text { ficar rico }\end{array}$ & $0,28^{* *}$ & $0,25^{* *}$ & 0,23 & 0,09 & $0,53^{* * *}$ \\
\hline Troca de voto por bem material & $0,14^{*}$ & 0,12 & $.0,07$ & 0,11 & $.0,20$ \\
\hline Ordem $\mathrm{x}$ injustiça & $0,13 * *$ & 0,10 & 0,04 & 0,07 & 0,18 \\
\hline $\begin{array}{l}\text { Se país é rico, não importa que haja } \\
\text { desigualdades }\end{array}$ & $0,20^{* * *}$ & 0,07 & $.0,04$ & 0,20 & $0,59 * *$ \\
\hline Política é para profissionais & $0,32 * *$ & $0,19 * *$ & $0,36 * *$ & $0,27 * *$ & 0,19 \\
\hline $\begin{array}{l}\text { A única solução para o país é o } \\
\text { socialismo }\end{array}$ & $.0,05$ & $.0,07$ & $.0,04$ & $0,20^{*}$ & $0,51^{* * *}$ \\
\hline Povo decidindo é melhor & $.0,04$ & $.0,08$ & 0,16 & 0,11 & $0,41^{* *}$ \\
\hline (\% Média de Eleitores) & $(70 \%)$ & $(63 \%)$ & $(74 \%)$ & $(76 \%)$ & $(87 \%)$ \\
\hline
\end{tabular}

Fonte: Cedec/USP/Datafolha - Setembro/89 (Universo: Brasil)

$\left.{ }^{*}\right)$ coef. significativo nível 0,$\left.05 ;{ }^{* *}\right)$ coef. signif. nível 0,01; demais coef. não signif. estatisticamente.

\footnotetext{
${ }^{13}$ No cálculo das correlações apresentadas nestas tabelas, as respostas às questões sobre opiniões dos eleitores foram operacionalizadas sempre como variáveis ordinais com três categorias (duas categorias extremas e uma intermediária, como "concorda totalmente", "concorda ou discorda em parte" e "discorda totalmente", ou ainda: "totalmente a favor", "a favor ou contra em parte" e "totalmente contra"). As categorias eram ordenadas em cada questão de forma a que a posição 1 fosse a mais democrática, igualitária, etc, e a posição 3 fosse o inverso. A expectativa teórica a ser testada, portanto, era a de que os eleitores com posições do tipo 1 tenderiam a se posicionar na escala proporcionalmente mais à esquerda e os com posições do tipo 3, proporcionalmente mais à direita, o que corresponderia a coeficientes positivos de correlação. Foi testada também uma ordem em que se invertia as posições ao centro e à esquerda, já que para algumas questões as posições esperadas poderiam ter esse ordenamento. Embora os coeficientes variem, a magnitude das correlações não é substancialmente diferente na quase totalidade dos casos. Como o interesse aqui é apenas o de verificar o grau em que opiniões e "posicionamentos ideológicos" se associam, estes últimos dados não são apresentados, porque não nos levariam a conclusões diferentes, para os objetivos da análise.
} 
TABELA 10

Correlação (Gama) entre opinióes políticas e posicionamento na escala esquerda-direita, Segundo escolaridade (Março/90)

\begin{tabular}{|c|c|c|c|c|c|}
\hline Questão (1) & $\begin{array}{l}\text { Conjunto } \\
\text { Eleitores }\end{array}$ & $\begin{array}{l}\text { Até } 1^{\circ} \\
\text { Grau Inc. }\end{array}$ & $\begin{array}{l}1^{\circ} \text { Grau } \\
\text { Completo }\end{array}$ & $2^{\circ} \mathrm{Grau}$ & Superior \\
\hline Democracia $\mathrm{x}$ ditadura & $-0,03$ & $-0,08$ & $-0,14$ & $-0,11$ & 0,08 \\
\hline $\begin{array}{l}\text { Minoria deve obedecer maioria, deixando } \\
\text { de lado suas idéias }\end{array}$ & $0,11^{* *}$ & 0,00 & 0,04 & $0,20 * *$ & $0,35 * *$ \\
\hline Líder forte x participação popular & $0,12^{* *}$ & 0,06 & $-0,09$ & 0,11 & $0,42^{* *}$ \\
\hline $\begin{array}{l}\text { Governo deve poder usar polícia contra } \\
\text { manifestações? }\end{array}$ & $0,28^{* *}$ & $0,15^{* *}$ & 0,15 & $0,28 * *$ & $0,33^{* *}$ \\
\hline $\begin{array}{l}\text { Governo deve poder processar quem for } \\
\text { contra autoridade? }\end{array}$ & $0,28 * *$ & $0,15^{* *}$ & $0,33^{* *}$ & $0,16^{* *}$ & $0,34 * *$ \\
\hline $\begin{array}{l}\text { Governo deve poder proibir (por leis) } \\
\text { manifestações de protesto? }\end{array}$ & $0,28^{* *}$ & 0,02 & $0,33^{* *}$ & $0,27^{* *}$ & $0,55^{* *}$ \\
\hline $\begin{array}{l}\text { Governo deve poder usar tropas para } \\
\text { acabar com greves? }\end{array}$ & $0,37^{* *}$ & $0,26 * *$ & 0,17 & $0,28 * *$ & $0,60 * *$ \\
\hline $\begin{array}{l}\text { É bobagem mudar leis, porque elas não } \\
\text { são respeitadas. }\end{array}$ & $0,09 *$ & 0,00 & 0,05 & 0,02 & $0,24^{*}$ \\
\hline Mudanças no Brasil só com violência & 0,05 & 0,01 & $-0,08$ & $-0,06$ & $-0,32$ \\
\hline $\begin{array}{l}\text { Melhor manter família que acabar } \\
\text { c/casamento infeliz }\end{array}$ & $0,26^{* *}$ & $0,13^{*}$ & 0,11 & $0,19 * *$ & $0,26 *$ \\
\hline Volta dos militares ao poder & $0,20 * *$ & 0,06 & 0,11 & 0,09 & 0,15 \\
\hline $\begin{array}{l}\text { Governo, protegendo os pobres, prejudica } \\
\text { quem trabalha }\end{array}$ & $0,21^{* *}$ & $0,11^{*}$ & 0,11 & 0,12 & 0,18 \\
\hline $\begin{array}{l}\text { No capitalismo quem se esforça pode } \\
\text { ficar rico }\end{array}$ & $0,27^{* *}$ & $0,19 * *$ & $0,35^{* *}$ & $0,23^{* *}$ & $0,37^{* * *}$ \\
\hline $\begin{array}{l}\text { País seria melhor se só existisse um } \\
\text { partido político }\end{array}$ & $0,19 * *$ & 0,03 & 0,10 & 0,02 & 0,00 \\
\hline $\begin{array}{l}\text { Melhor caminho } \mathrm{p} / \text { ajudar os pobres é c/ } \\
\text { ajuda do governo }\end{array}$ & $0,25^{* *}$ & $0,17^{*}$ & 0,10 & 0,17 & 0,08 \\
\hline $\begin{array}{l}\text { No Brasil só deveriam votar as pessoas } \\
\text { com estudo }\end{array}$ & 0,05 & 0,00 & 0,10 & 0,02 & $0,23^{*}$ \\
\hline $\begin{array}{l}\text { Se o país for rico não importa que haja } \\
\text { desigualdade social }\end{array}$ & $0,22^{* *}$ & 0,06 & $0,32^{* *}$ & 0,09 & 0,14 \\
\hline $\begin{array}{l}\text { A única solução para o país é o } \\
\text { socialismo }\end{array}$ & $\cdot 0,05$ & $-0,10$ & 0,05 & 0,13 & $0,61 * *$ \\
\hline (\% Média de Eleitores) & ( $77 \%)$ & $(67 \%)$ & $(81 \%)$ & $(85 \%)$ & $(92 \%)$ \\
\hline
\end{tabular}

Fonte: Cedec/USP/Datafolha - Setembro/89 (Universo: Brasil)

$\left(^{*}\right)$ coef. significativo nível 0,05; $\left(^{* *}\right)$ coef. signif. nível 0,01; demais coef. não signif. estatisticamente. 
Correlação entre opiniões políticas e autoposicionamento na escala esquerda-direita (Nov./97)

\begin{tabular}{|l|c|c|c|}
\hline \multicolumn{1}{|c|}{ Questão } & $\begin{array}{c}\text { Conjunto } \\
\text { Eleitores }\end{array}$ & $\begin{array}{c}\text { Até } 1^{\circ} \text { Grau } \\
\text { Incompleto }\end{array}$ & Superior \\
\hline Socialismo como solução para os problemas sociais & $\cdot 0,11$ & $\cdot 0,13$ & 0,15 \\
\hline Democracia x ditadura & 0,01 & 0,01 & $\cdot 0,28$ \\
\hline $\begin{array}{l}\text { Minoria deve obedecer maioria, deixando de lado suas } \\
\text { idéias }\end{array}$ & 0,00 & $\cdot 0,04$ & 0,18 \\
\hline Líder forte x participação popular & $0,21^{* *}$ & 0,11 & $0,61^{* *}$ \\
\hline $\begin{array}{l}\text { Para manter a ordem, as leis, mesmo injustas, devem ser } \\
\text { obedecidas }\end{array}$ & 0,03 & 0,01 & 0,14 \\
\hline Mudanças no Brasil só com revolução ou pela força & 0,07 & 0,10 & 0,11 \\
\hline Política é para profissionais (deputados; senadores) & $0,19^{*}$ & 0,07 & 0,34 \\
\hline $\begin{array}{l}\text { Não há solução para problemas sociais sem reforma agrária } \\
\text { radical }\end{array}$ & 0,08 & 0,05 & 0,34 \\
\hline País funcionaria melhor c/ a volta dos militares ao poder & 0,15 & 0,13 & 0,41 \\
\hline Governo deve poder proibir greves & $0,22^{* *}$ & $0,25^{*}$ & 0,36 \\
\hline Governo deve poder intervir nos sindicatos & 0,03 & 0,07 & 0,26 \\
\hline Governo deve poder proibir a existência de algum partido & 0,11 & 0,21 & $\cdot 0,06$ \\
\hline Governo deve poder censurar jornais, TVs e rádio & 0,10 & 0,04 & $\cdot 0,41$ \\
\hline Governo deve poder fechar o Congresso Nacional & $\cdot 0,14$ & $\cdot 0,12$ & 0,13 \\
\hline (\% Média de Eleitores) (1) & $(71 \%)$ & $(65 \%)$ & $(89 \%)$ \\
\hline Fonte:Fundaço Perseu Abramo - Nücleo & & & \\
\hline
\end{tabular}

Fonte: Fundação Perseu Abramo - Núcleo de Opinião Pública - Novembro/97 (Universo: Brasil).

$\left(^{*}\right)$ coef. significativo nivel 0,05; $\left(^{* *}\right)$ coef. signif. nivel 0,01; demais coef. não signif. estatisticamente.

(1) São indicadas as porcentagens médias de eleitores, em cada categoria, a partir das quais foram feitos os cálculos dos coeficientes de correlação. Há uma variação relativamente pequena em torno dessas médias. Isso nos dá uma indicação das proporções de missing cases, em cada análise.

Antes mesmo de analisar os dados, vale a pena indicar que, embora não tenham sido mostrados aqui dados relativos às correlações entre as respostas dos eleitores a todas estas questões (umas com as outras), os resultados preliminares de uma análise panorâmica destas correlações revelam muitas variações entre eleitores e entre tipos de questões: em geral, há maior "coerência" entre opiniões frente a temas correlatos (por exemplo, diversas questões sobre participação política) do que entre temas diferentes (por exemplo, opiniões sobre participação política podem não ser muito "coerentes" com opiniões sobre intervenção do Estado na economia); a "coerência" em geral é maior entre eleitores com maior nível de escolaridade, do que entre os de menor escolaridade. ${ }^{14}$

Sem entrar em detalhes sobre os dados das tabelas 9 a 11 , as principais conclusões que importa aqui destacar são:

\footnotetext{
${ }^{14}$ Esses são resultados muito gerais, que ressaltam numa análise panorâmica. Não foi possível no âmbito deste trabalho um tratamento destes dados com o rigor e a sistematicidade que seriam adeqüados.
} 
a) para o conjunto dos eleitores, embora as associações entre o autoposicionamento na escala esquerda-direita e suas opiniões políticas sejam quase todas fracas, há algumas associações moderadas;

b) entre os eleitores de mais alta escolaridade, há várias associações de força moderada a substancial entre seu autoposicionamento na escala e as opiniões relativas a diversas dimensões (e não só aquela destacada por Singer) ${ }^{15}$;

c) entre os eleitores com menor escolaridade, o grau de associação entre opiniões políticas específicas e o autoposicionamento dos eleitores na escala esquerda. direita é relativamente baixo para todas as questões analisadas. De toda forma, mesmo entre eles a grande maioria das associações é positiva (44 casos em 55) e muitas delas (14) estatisticamente significativas. Isso parece indicar que há uma certa tendência, ainda que bem mais fraca, semelhante à existente entre os eleitores de alta escolaridade: comparativamente havia proporções maiores de eleitores que se posicionavam à esquerda apresentando opiniões democráticas, igualitárias, favoráveis à participação popular do que as proporções de eleitores que se posicionavam à direita que apresentavam estes tipos de opiniões. ${ }^{16}$

d) Para o conjunto de eleitores, e especialmente entre os de menor escolaridade, embora os baixos coeficientes de correlação (em média) não apontem para um grau de associação muito substancial entre posicionamento na escala e opiniões políticas, a clivagem proposta por Singer (1998) (inclusive a partir de alguns dos dados aqui utilizados) parece ser realmente a mais importante para diferenciar o conjunto dos eleitores, segundo seu autoposicionamento na escala.

Assim, uma parcela dos eleitores que se posicionaria tendencialmente mais à direita parece realmente perceber certas manifestações políticas (greves, manifestações de protesto, mobilizações populares em geral) como negativas (sinais de "desordem", "baderna"), rejeitando os candidatos e partidos associados a este tipo de ação política e esperando que as mudanças políticas ocorram "dentro da ordem", a partir das "autoridades constituídas", ou de um "líder forte". Outra parcela dos eleitores, que se posicionaria tendencialmente mais à esquerda, ao contrário, perceberia aquele tipo de ação política como necessária, ou pelo menos válida, para a obtenção de mudanças sociais, e tenderia a votar nos candidatos mais vinculados às mobilizações populares. ${ }^{17}$

\footnotetext{
${ }^{15}$ No survey de novembro de 1997 o fato da maioria dos coeficientes ser estatisticamente não-significativa se deve, em boa parte, ao fato do número de entrevistados com nível superior que entraram na análise ser muito baixo.

${ }^{16}$ É importante notar que uma análise de correlação entre as opiniões dos eleitores diretamente com suas intenções de voto (e não mais com seu autoposicionamento na escala esquerda-direita) revela dados semelhantes: em geral baixos coeficientes para o conjunto do eleitorado; coeficientes bem menores entre os eleitores de menor escolaridade do que entre os eleitores de nível superior. Assim, pode-se inferir que os menores coeficientes encontrados entre os eleitores de menor escolaridade nas tabelas 9, 10 e 11 não se devem apenas a uma não compreensão da escala esquerda-direita por parte daqueles eleitores, mas também ao fato de que suas opiniões políticas têm mesmo menor relevância em outros aspectos de seu comportamento político (comparativamente aos eleitores com nível superior).

${ }^{17}$ Embora não para todos ocorra esta associação. Assim, por exemplo, nem todos os eleitores que tinham opiniões favoráveis à mobilização popular e votavam em Lula se posicionavam à esquerda na escala. Mas, de toda forma, as intenções de voto têm
} 


\section{Considerações finais}

Antes de sistematizar os principais resultados encontrados, creio valer a pena fazer um breve exercício lógico sobre alguns dos possíveis significados do autoposicionamento do eleitor numa escala esquerda-direita e sua relação com o voto.

a) Uma primeira possibilidade é a de que este posicionamento reflita realmente uma compreensão "adeqüada" dos termos "esquerda" e "direita" e esteja associado a um "sistema de crenças" razoavelmente estruturado. Daí poderia resultar um voto em conformidade com este posicionamento: um "voto ideológico" em sentido mais forte;

b) Uma segunda possibilidade é a de que para uma parcela dos eleitores os termos "esquerda" e "direita" não tenham nenhum significado político e que estes eleitores, além disso, sequer identifiquem quais os partidos e candidatos seriam considerados como sendo de esquerda ou de direita. Neste caso, teríamos: b1) um sub-conjunto (desta parcela) que não se posiciona na escala; b2) um outro sub. conjunto poderia se posicionar apenas para não passar por desinformado perante 0 entrevistador (sua resposta corresponderia ao que Converse chama de "non-opinion"). Teríamos, então, pelo menos dois resultados: não haveria coincidência entre posicionamento na escala e voto, ou haveria esta coincidência, mas seria devida apenas ao acaso.

c) Uma terceira possibilidade é a de que o eleitor, apesar de não ter um "sistema de crenças" estruturado, nem conhecer as posições políticas dos partidos e candidatos em relação a vários issues, associa os termos "esquerda" e "direita" a polarizações cujos significados têm graus variados de proximidade com o significado mais aceito daquela polarização e vota em conformidade com isso. Mas, neste caso, dependendo daqueles significados, poderiam ocorrer diferentes relações de causalidade entre "posicionamento ideológico" do eleitor e seu voto. Uma delas seria a proposta na tese de Singer sobre o voto por "identificação ideológica"; outras possibilidades, porém, serão esboçadas mais à frente.

Se a sistematização das principais conclusões a respeito do conjunto dos dados analisados ao longo do trabalho não permite identificar com precisão a dimensão em que se efetiva cada uma das possibilidades acima, permite pelo menos algumas suposições abrangentes.

Quanto à compreensão pelos eleitores dos termos esquerda e direita (necessária para a compreensão do significado de uma escala do tipo utilizado), embora haja variações, tomando as porcentagens médias dos surveys, temos a seguinte

correlações menores com as opiniões dos eleitores frente àquela polaridade destacada por Singer ("autoridade forte" $\mathrm{x}$ "mobilização popular") do que com o autoposicionamento dos eleitores na escala esquerda-direita, o que parece fazer deste último (até por ser mais sintético e estar associado a outras opiniões dos eleitores) um melhor previsor do voto do que simplesmente suas opiniões frente àquela polaridade substantiva. 
situação: em média, cerca de $42 \%$ dos eleitores não conseguiram verbalizar qualquer significado político para as noções de "esquerda" e "direita", quando solicitados a fazêlo. O percentual médio de respostas que poderiam ser aceitas como mais ou menos adeqüadas (incluindo aí, com certo grau de boa vontade, as definições de "direita" como "ser do governo" e de "esquerda" como "ser contra o governo") foi de cerca de 1/3 dos eleitores. Há, porém, diferenças significativas entre os eleitores, segundo sua escolaridade: declinam bastante, com o crescimento da escolaridade, as porcentagens de eleitores que não conseguem verbalizar nada para explicar o que entendem por "esquerda" e "direita" (média de $52 \%$ entre os eleitores com até $1^{\circ}$ grau completo e de $12 \%$ entre os eleitores com nível superior). As respostas que poderiam ser consideradas como mais ou menos adeqüadas, por sua vez, cresciam com o grau de escolaridade.

Isso mostra que o grau de compreensão sobre as noções envolvidas numa escala esquerda-direita varia muito com a escolaridade do eleitor. Mas as diferenças não ocorrem apenas em relação à capacidade de verbalização; elas ocorrem frente ao próprio ato de se posicionar na escala. Para o conjunto do eleitorado, as proporções de eleitores que se posicionavam na escala variaram de 75 a $80 \%$ da amostra (conforme o survey), o que significa que para 20 a $25 \%$ do conjunto dos eleitores este não é um indicador que possa ser utilizado para prever seu voto. Distinguindo os eleitores pelo grau de escolaridade, temos um quadro bastante diferenciado: enquanto entre os eleitores sem escolaridade a taxa média dos que não se posicionavam na escala foi de $46 \%$, esta taxa decai, entre aqueles com alguma escolaridade até $1^{\circ} \mathrm{Grau}$ incompleto, para $25 \%$, chegando a $8 \%$ entre os eleitores com nível superior. Ou seja, não só pelas diferenças de compreensão, mas também pelo percentual dos que se posicionam na escala já temos grandes diferenças quanto à eficiência do autoposicionamento na escala como um possível preditor do voto.

Mas, mesmo quando consideramos apenas aqueles eleitores que se posicionam neste tipo de escala, há diferenças significativas também quando analisamos a associação entre este posicionamento e seu voto, sua preferência partidária e suas opiniões frente a questões políticas específicas. Assim, entre os eleitores sem nenhuma escolaridade, dos cerca de $54 \%$ (em média) que se posicionam na escala, as associações entre esse posicionamento e o voto são negativas; entre os com até $1^{\circ}$ Grau incompleto, dos cerca de $75 \%$ (em média) que se posicionam numa escala, as associações entre esse posicionamento e o voto variaram de fracas a moderada (uma delas). Por outro lado, entre os eleitores com nível superior de escolaridade, apenas 8 $\%$ deles (em média) não se autoposicionam na escala; entre os restantes $92 \%$ as correlações com o voto vão de substanciais (coeficiente mínimo é de 0,65) a muito fortes (máximo de 0,82). ${ }^{18}$

\footnotetext{
${ }^{18}$ Os dados relativos à associação entre o autoposicionamento dos eleitores na escala E/D e sua preferência partidária revelam um padrão semelhante a este. As variações entre eleitores quanto à associação entre o voto e a resposta à pergunta sobre preferência
} 
Explorando um pouco mais algumas das categorias de respostas mais freqüentes à questão sobre o significado da polaridade esquerda/direita e a relação entre este significado e o voto, constata-se que para uma parcela significativa de eleitores (19 a $28 \%$ do eleitorado nacional, conforme o survey) aquela polarização parece estar associada a "ser contra o governo" (esquerda) x "ser governo" (direita). 0 problema é que mesmo nos casos em que há realmente uma coincidência, ou seja, a esquerda está na oposição e a direita (ou a centro-direita) está no governo ${ }^{19}$, as relações de causalidade não são evidentes. ${ }^{20}$ Cerca de $10 \%$ dos eleitores, por sua vez, verbalizam o significado daqueles termos associando "esquerda" ao que é "errado" e direita ao que é "certo". ${ }^{21}$ Não se pode, a princípio, fazer qualquer inferência precisa a partir daí, já que a avaliação do que o eleitor considera como "certo" ou "errado" não é evidente. Como, porém, praticamente todos os eleitores que definiram desta forma se localizaram à direita ou ao centro da escala (não se posicionando do lado do que "é errado"), mas uma parcela razoável indicava intenção de voto à esquerda, fazer uma previsão do voto destes eleitores com base em seu posicionamento na escala resulta numa subestimação do voto à esquerda. ${ }^{22}$

por um candidato situado mais à esquerda ou à direita também seguem um padrão semelhante.

${ }^{19}$ Em 1994 e 1998, grosso modo a situação era essa. Em 1989 tanto Collor quanto Lula estavam na oposição e obviamente isto não significa que Collor era de esquerda. No caso de um partido de esquerda estar no poder, a questão se complicaria mais: como estes eleitores identificariam este partido ? Como de direita, por estar no poder ? De toda forma, a correlação $($ de 0,53$)$ entre posicionamento na escala e voto mostra que grande parte do eleitorado identificava "corretamente" o posicionamento ideológico dos dois candidatos.

${ }^{20}$ Para parte destes eleitores poderia ocorrer uma seqüência como a exemplificada a seguir: um eleitor, em 1998, avalia o governo FHC negativamente com base em seu desempenho na consecução de objetivos "consensuais"; a partir daí, ao se posicionar na escala esquerda-direita (quando solicitado a fazê-lo por um entrevistador), pode se posicionar como de esquerda, no sentido de que se sente em oposição ao governo, por avaliar que este está fazendo uma má administração. Isto não significa necessariamente que este eleitor tenha posições políticas próximas às defendidas pela esquerda, nem que sua intenção de voto vá para Lula. $\mathrm{O}$ eleitor, avaliando negativamente o governo, poderá anular seu voto ou votar em um candidato de oposição, mas não necessariamente um candidato situado à esquerda. Mesmo no caso de ter votado em Lula (ou seja, mesmo havendo concordância entre seu posicionamento na escala esquerda-direita e seu voto), este não seria necessariamente um "voto ideológico", em sentido forte, nem um voto com base em uma visão política simplificada (um voto com base numa "imagem" ou "identificação ideológica" mais vagamente definida). O eleitor poderia ter votado em Lula apenas porque ele era o único com chance de derrotar o candidato governista. Como se vê, neste caso, as relações de causalidade seriam bem diferentes: tratar-se-ia aí, ao contrário, de um voto motivado por avaliação de desempenho do governo. A correlação entre o posicionamento do eleitor na escala esquerda-direita e seu voto seria "espúria", já que estas duas variáveis seriam determinadas por uma terceira.

${ }^{21}$ Há, porém, grandes diferenças entre os eleitores, segundo sua escolaridade: no survey realizado pelo Cedec/USP/Datafolha em setembro de 1989 , por exemplo, enquanto de 12 a $15 \%$ dos eleitores de baixa escolaridade atribuíam estes significados aos termos "esquerda" e "direita", entre os eleitores com nível superior só 1 a 2 \% o faziam.

${ }^{22} \mathrm{Se}$ tomamos os dados do survey realizado pelo Cedec/USP/Datafolha em setembro de 1989, tínhamos as seguintes distribuições dos eleitores, segundo seu posicionamento na escala e sua intenção de voto: $12 \%$ se posicionavam na esquerda, mas $23 \%$ pretendiam votar em candidatos considerados de esquerda; $39 \%$ se posicionavam ao centro, mas apenas $12 \%$ pretendiam votar em candidatos situados no centro; $23 \%$ se posicionavam à direita, mas $49 \%$ pretendiam votar em candidatos de direita. Neste caso pode-se explicar parte destas discrepâncias pelo fato de que a péssima avaliação do governo (identificado predominantemente com o PMDB, partido localizado no centro do espectro político-ideológico) levou ao voto em candidatos de esquerda ou direita, em franca oposição a Sarney. Mas no survey realizado pela Fundação Perseu Abramo em novembro de 1997 este problema não existia e persistia o problema da subestimação dos votos na esquerda a partir do posicionamento dos eleitores na escala: enquanto apenas $13 \%$ se posicionavam à esquerda na escala, $27 \%$ pretendiam votar em candidatos situados à esquerda; $35 \%$ se localizavam ao centro e $27 \%$ à direita (somando $62 \%$ do eleitorado), mas apenas $50 \%$ pretendiam votar em candidatos situados no centro ou na direita. (Foram considerados juntos o centro e a direita, porque seguindo a hipótese, FHC deveria atrair os votos de boa parte dos eleitores da direita, já que Enéas tinha poucas chances eleitorais. Se considerarmos apenas a direita isoladamente, a discrepância seria ainda maior). 
Parece haver, para cada faixa de escolaridade dos eleitores, uma combinação diferente dos comportamentos acima descritos naquele exercício lógico: entre os eleitores de maior escolaridade há maior proporção de eleitores naquela primeira situação, ou seja, eleitores "ideológicos". Indícios nesta direção vêm dos coeficientes de correlação de ordem moderada encontrados nesta faixa de eleitores entre diversas opiniões políticas específicas entre si, havendo, além disso, correlações de ordem moderada ou substancial de algumas de suas opiniões com seu posicionamento na escala esquerda-direita e com seu voto. Mas os dados não permitem dizer que os eleitores "ideológicos" sejam maioria mesmo entre os eleitores de nível superior. As correlações entre as diversas opiniões específicas destes eleitores, apesar de maiores do que as existentes entre os eleitores de menor escolaridade, não são altas, sendo de ordem moderada, em sua maioria. Além disso, a alta proporção de eleitores nesta faixa para os quais esquerda e direita significam ser contra e a favor do governo, permite supor que parte dos relativamente altos coeficientes de correlação entre posicionamento na escala e voto encontrados nesta faixa de eleitores não se deva necessariamente a um "voto ideológico", podendo se dever a outros daqueles tipos de comportamento: um voto com base numa "imagem" ou "identificação ideológica" mais vaga ou um voto cuja motivação está associada mais à avaliação de desempenho do governo do que à "ideologia". Por outro lado, há entre estes eleitores menores proporções dos que não se posicionam na escala e dos que não sabem verbalizar um significado para os termos "esquerda" e "direita", o que significa também menores chances de ocorrer um voto sem nenhuma relação com o posicionamento na escala.

Quanto aos eleitores de menor escolaridade, um "voto ideológico", no sentido forte (baseado em um "sistema de crenças" mais estruturado), é ainda mais raro do que entre os eleitores com alta escolaridade, no que, aliás, o eleitorado brasileiro não parece se diferenciar muito do da maioria dos países. Além disso, considerando que só uma pequena parcela destes eleitores tem uma compreensão razoavelmente adequada dos termos que compõem a escala e que $25 \%$ em média sequer se posicionam na escala - não podendo, portanto, o voto derivar deste (não) posicionamento - é possível dizer que não só o "voto ideológico", mas também um voto baseado em alguma "imagem" ou "identificação ideológica" mais vaga, têm um peso menor do que o que têm entre os eleitores com maior escolaridade. Por outro lado, para estes eleitores (excluindo os sem nenhuma escolaridade, cujas correlações são negativas), dado que os coeficientes de correlação entre posicionamento na escala e voto são, apesar de baixos ou moderados, positivos (e alguns deles estatisticamente significativos), pode-se supor haja, dentre estes eleitores, uma parcela um pouco maior do que a que seria esperada apenas devida ao acaso, para a qual há coincidência entre o posicionamento na escala e o voto.

A conclusão mais geral, portanto, é a de que o uso do autoposicionamento dos eleitores na escala esquerda-direita tem maior eficácia se acoplado à variável 
escolaridade. Do ponto de vista explicativo, isso permite uma melhor compreensão dos significados substantivos daquele posicionamento para os diferentes eleitores e, portanto, de seu processo de tomada de decisão. Especialmente importante é o fato de que para compreender o comportamento da maioria dos eleitores brasileiros de alta escolaridade (e de parcela substancial dos eleitores de escolaridade média) parece necessário incluir em um modelo explicativo do voto mais completo, algum indicador da dimensão ideológica, e o posicionamento dos eleitores na escala E/D parece ser um indicador razoavelmente eficaz dessa dimensão, pelo menos para estes eleitores.

Do ponto de vista preditivo, a inclusão da variável escolaridade (ou "sofisticação política") permite distingüir os tipos de eleitores para os quais poderemos ter uma previsão mais ou menos acurada do voto a partir daquele posicionamento. Especialmente entre os eleitores de baixa escolaridade, a previsão de voto feita com base neste indicador tende a subestimar o voto à esquerda. Por outro lado, mesmo levando esta última tendência em consideração, há alguns elementos que sugerem que o posicionamento na escala esquerda/direita possa ser útil na previsão do voto. Em primeiro lugar, apesar da maior parcela dos eleitores expressar significados para as noções "esquerda" e "direita" associados a posicionamentos frente ao governo (ser contra ou a favor, respectivamente), um caso significativo parece ser o do $2^{\circ}$ turno da eleição presidencial de 1989, quando tanto Collor quanto Lula se apresentaram claramente como oposição a Sarney; mesmo assim, a correlação entre o voto e o posicionamento dos eleitores (medida em survey Cedec/USP/Datafolha) foi substancial (coeficiente de 0,53). Ou seja, a parcela do eleitorado que votou em conformidade com seu posicionamento na escala foi maior do que aquela que seria de esperar a partir dos significados verbalizados para os termos esquerda e direita. Além disso, do ponto de vista preditivo, como as correlações entre o voto e as opiniões políticas (e mesmo alguns índices, aglutinando diversas opiniões) foram menores do que as correlações entre voto e posicionamento na escala, este último parece ser um indicador mais adeqüado (pelo menos até encontrarmos algum outro) de um componente ideológico que parece fazer parte dos fatores que influenciam a decisão de voto para presidente de parcela significativa dos eleitores brasileiros, especialmente os de maior escolaridade.

Concluindo, a proposta de Singer de inclusão de um componente de ordem ideológica parece pertinente num modelo que pretenda compreender o comportamento político de parcela significativa do eleitorado brasileiro, especialmente os eleitores de maior escolaridade. Além disso, até o momento, pelo menos do ponto de vista preditivo o autoposicionamento dos eleitores numa escala esquerda/direita parece ser o indicador mais sintético de um tal componente. Por outro lado, parece exagerado o peso dado por aquele autor a esse componente, já que outras variáveis (ver Carreirão, 2000) revelaram ter maior influência na determinação dos resultados das eleições presidenciais brasileiras recentes. 


\section{BIBLIOGRAFIA}

CAMPBELL, Angus, et al. (1960) The American Voter. New York, Wiley. 1960.

CARREIRÃO, Yan S. (2000) A Decisão do Voto nas Eleições Presidenciais no Brasil (1989 a 1998): a Importância do Voto por Avaliação de Desempenho. São Paulo, Tese de Doutorado, FFLCH/USP.

CASTRO, Mônica M.M. (1994) Determinantes do comportamento eleitoral. A centralidade da sofisticação política. Rio de Janeiro, Tese de Doutorado, IUPERJ.

CONVERSE, Phillip. (1964) The nature of belief systems in mass publics. In: APTER, David (ed.) Ideology and discontent. New York, Free Press.

DAVIS, James. (1976) Levantamentos de dados em sociologia: uma análise estatística elementar. Rio de Janeiro, Zahar.

FIGUEIREDO, Argelina \& LIMONGI, Fernando F. (1999) Executivo e legislativo na nova ordem constitucional. Rio de Janeiro, FAPESP / Editora FGV.

FIORINA, Morris (1981) Retrospective Voting in American national elections. New Haven, Yale University Press.

LEVITIN, Teresa \& MILLER, Warren. (1979) Ideological interpretations of presidential elections. American Political Science Review, 73 (3). Washington, American Political Science Association.

KINZO, Maria D'Alva. (1990) O quadro partidário e a constituinte. In: LAMOUNIER, Bolívar (org.). De Geisel a Collor: o balanço da transição. São Paulo, IDESP/Sumaré.

MILLER, Warren \& SHANKS, J. Merrill. (1996) The new american voter. Cambridge, Harvard University Press.

NEUMAN, W. Russel. (1986) The paradox of mass politics - knowledge and opinion in the American electorate. Cambridge, Harvard University Press.

SARTORI,Giovanni. (1982) Partidos e sistemas partidários. Brasília, UnB.

SINGER, André. (1993) Ideologia e voto no segundo turno da eleição presidencial de 1989. São Paulo, Dissertação de Mestrado, FFLCH/USP.

. (1998) Identificação ideológica e voto no Brasil: o caso das eleições presidenciais de 1989 e 1994. São Paulo, Tese de Doutorado, FFLCH/USP. 


\section{TABELAS ANEXAS}

TABELA ANEXA 1

Significado de "esquerda", segundo Escolaridade - (Maio/93) (\%)

\begin{tabular}{|l|c|c|c|c|}
\hline \multicolumn{1}{|c|}{ Significado de "Esquerda" } & Conjunto & \multicolumn{3}{c|}{ Escolaridade } \\
\cline { 3 - 5 } & Eleitores & Até $1^{\circ} \mathrm{G}$. & $2^{\circ}$ Grau & Superior \\
\hline Não sabe/ não respondeu & 47 & 58 & 38 & 12 \\
\hline Contra o governo/ sistema/ poder; ser da oposição & & & \\
& 20 & 12 & 27 & 40 \\
\hline $\begin{array}{l}\text { Defende interesses do povo/ maioria/ trabalhadores; estar } \\
\text { ao lado da classe baixa; igualdade; direitos sociais. }\end{array}$ & 8 & 4 & 10 & 21 \\
\hline É o comunismo/ socialismo & 4 & 3 & 6 & 8 \\
\hline É o errado/ o pior/ o lado negativo & 3 & 5 & 2 & 0 \\
\hline Não tem diferença (entre E e D) & 3 & 3 & 3 & 6 \\
\hline Outras respostas & 15 & 16 & 15 & 15 \\
\hline
\end{tabular}

Fonte: Datafolha / Maio/93 (Universo: Brasil - $N=2500$ ).

\section{TABELA ANEXA 2}

Significado de "direita", segundo escolaridade - (Maio/93) (\%)

\begin{tabular}{|c|c|c|c|c|}
\hline \multirow[b]{2}{*}{ Significado de "Direita" } & \multirow{2}{*}{$\begin{array}{l}\text { Conjunto } \\
\text { Eleitores }\end{array}$} & \multicolumn{3}{|c|}{ Escolaridade } \\
\hline & & Até $1^{\circ} \mathrm{G}$. & $2^{\circ} \mathrm{Grau}$ & Superior \\
\hline Não sabe/ não respondeu & 47 & 57 & 39 & 13 \\
\hline $\begin{array}{l}\text { Ser, apoiar o governo, o sistema/ poder; ser do partido do } \\
\text { presidente; lutar para que nada mude }\end{array}$ & 20 & 13 & 28 & 40 \\
\hline É o certo/ o melhor/ o direito; o caminho certo & 6 & 8 & 3 & 0,4 \\
\hline $\begin{array}{l}\text { É defender os interesses do povo/ da maioria/ dos } \\
\text { trabalhadores; estar ao lado da classe baixa; igualdade; } \\
\text { direitos sociais }\end{array}$ & 4 & 5 & 3 & 1 \\
\hline $\begin{array}{l}\text { É defender os interesses dos empresários/ das elites; estar } \\
\text { ao lado dos ricos/ dos banqueiros/ da burguesia; não pensa } \\
\text { no povo; desigualdade social }\end{array}$ & 4 & 2 & 4 & 14 \\
\hline Não tem diferença (entre E e D) & 3 & 3 & 3 & 6 \\
\hline $\begin{array}{l}\text { É fazer conchavos; defender os próprios interesses; fazer do } \\
\text { jeito que os políticos querem }\end{array}$ & 2 & 1 & 3 & 4 \\
\hline $\begin{array}{l}\text { É defender valores tradicionais/ conceitos conservadores: } \\
\text { família, Deus, Pátria, moral }\end{array}$ & 2 & 0,4 & 2 & 7 \\
\hline Outras respostas & 13 & 12 & 15 & 16 \\
\hline
\end{tabular}

Fonte: Datafolha / Maio/93 (Universo: Brasil - N = 2500). 
TABELA ANEXA 3

Significado de "esquerda", segundo escolaridade - (Nov./97) (\%)

\begin{tabular}{|l|c|c|c|c|}
\hline \multicolumn{1}{|c|}{ Significado de "Esquerda" } & Conjunto & \multicolumn{3}{c|}{ Escolaridade } \\
\cline { 3 - 5 } & Eleitores & Até $1^{\circ}$ G. & $2^{\circ}$ Grau & Superior \\
\hline Não sabe/ não respondeu & 36 & 44 & 27 & 14 \\
\hline Ser contra o governo/ o poder; oposição & 28 & 22 & 37 & 42 \\
\hline Coisas negativas (p/nós; p/Brasil) & 9 & 12 & 5 & 2 \\
\hline Contra alguma coisa; contra tudo; só criticam & 5 & 5 & 6 & 6 \\
\hline Estar ao lado/ defender povo/ trabalhadores/fracos & 4 & 4 & 3 & 8 \\
\hline $\begin{array}{l}\text { Fazer manifestações/ greves; ser radical/ extremista; fazer } \\
\text { confusão/ baderna/ desordem }\end{array}$ & 3 & 1 & 7 & 10 \\
\hline $\begin{array}{l}\text { Igualdade; lutar por direitos sociais; voltado para } \\
\text { problemas sociais }\end{array}$ & 2 & 1 & 2 & 10 \\
\hline Ser comunista/ socialista; estatizar as indústrias & 2 & 1 & 1 & 4 \\
\hline
\end{tabular}

Fonte: Fundação Perseu Abramo - Núcleo de Opinião Pública - Nov./97 (Universo: Brasil)

Obs: As porcentagens foram calculadas sobre o número de eleitores, em cada faixa de escolaridade, que responderam à questão (aplicada apenas a uma sub-amostra de 480 entrevistados).

TABELA ANEXA 4

Significado de "direita", segundo escolaridade - (Nov./97) (\%)

\begin{tabular}{|l|c|c|c|c|}
\hline \multicolumn{1}{|c|}{ Significado de "Direita" } & $\begin{array}{c}\text { Conjunto } \\
\text { Eleitores }\end{array}$ & Até $1^{\circ} \mathrm{G}$. & $2^{\circ}$ Grau & Superior \\
\hline Não sabe/ não respondeu & 34 & 41 & 25 & 12 \\
\hline É a favor do governo; ligado ao governo & 22 & 18 & 33 & 24 \\
\hline É sempre quem está no poder; situação; status quo & 8 & 6 & 4 & 12 \\
\hline É o melhor/ bom/ certo; o caminho certo/ sérios & 11 & 15 & 13 & 6 \\
\hline $\begin{array}{l}\text { Defende empresários/ ricos/ classe alta; é contra o povo/ } \\
\text { os trabalhadores; } \\
\text { extremo ó capitalismo/ capitalismo }\end{array}$ & 3 & 3 & 1 & 12 \\
\hline Defende pobres/ trabalhadores & & & \\
\hline $\begin{array}{l}\text { São os conservadores/ reacionários; é contra os } \\
\text { comunistas/ socialistas }\end{array}$ & 1 & 1 & 2 & 6 \\
\hline Ë mais calmo/ tranqüilo; resolve sem tumulto & 1 & 0 & 3 & 2 \\
\hline
\end{tabular}

Fonte: Fundação Perseu Abramo - Núcleo de Opinião Pública - Nov./97 (Universo: Brasil)

Obs: As porcentagens foram calculadas sobre o número de eleitores, em cada faixa de escolaridade, que responderam à questão (aplicada apenas a uma sub-amostra de 480 entrevistados). 
TABELA ANEXA 5

Correlação entre intenção de voto e posicionamento na escala esquerda-direita - diferentes formas de operacionalizar as variáveis - (Nov./97)

\begin{tabular}{c|c|c|c|c|c}
\hline $\begin{array}{c}\text { Operacionalização das } \\
\text { variáveis }\end{array}$ & Conjunto Eleitores & $\begin{array}{c}\text { Até } 1^{\circ} \text { Grau } \\
\text { Incompleto }\end{array}$ & $\begin{array}{c}1^{\circ} \text { Grau } \\
\text { Completo }\end{array}$ & $2^{\circ}$ Grau & Superior \\
\hline$(1)$ & $0,26^{* *}$ & 0,20 & $0,51^{* *}$ & 0,18 & $0,77^{* *}$ \\
\hline$(2)$ & $0,28^{* *}$ & 0,28 & 0,36 & 0,19 & $0,94^{* *}$ \\
\hline$(3)$ & $0,27^{* *}$ & 0,21 & $0,42^{* *}$ & 0,19 & $0,80^{* *}$ \\
\hline$(4)$ & $0,22^{* *}$ & 0,13 & 0,19 & 0,13 & $0,81^{* *}$ \\
\hline$(5)$ & $0,31^{* *}$ & $0,23^{*}$ & $0,50^{* *}$ & 0,26 & $0,71^{* *}$ \\
\hline$N^{\circ}$. Casos (N) & $(303)$ & $(152)$ & $(38)$ & $(76)$ & $(37)$ \\
\hline
\end{tabular}

Fonte: Fundação Perseu Abramo - Núcleo de Opinião Pública (Universo: Brasil)

$\left({ }^{*}\right)$ coeficientes significativos ao nível 0,$05 ;\left({ }^{*}\right)$ coeficientes significativos ao nível 0,01; demais coeficientes estatisticamente não significativos;

(1) Posicionamento na escala: esquerda = posições 1 e 2 da escala; centro = posições 3 a 5; direita = posições 6 e 7; intenção de voto: esquerda = Lula e Ciro; centro = FHC e Sarney; direita = Enéas; (2) Posicionamento na escala: idem (1); intenção de voto: esquerda = Lula; centro = FHC, Ciro e Sarney; direita = Enéas; (3) Posicionamento na escala: idem (1); intenção de voto: esquerda = Lula; centro-esquerda =Ciro; centro-direita = FHC e Sarney; direita = Enéas; (4) Posicionamento na escala: idem (1); intenção de voto: esquerda = Lula; centro = Ciro e FHC; direita = Sarney e Enéas; (5) Posicionamento na escala: esquerda = posição 1 da escala; centro-esquerda = posições 2 e 3; centro = posição 4; centro-direita = posições 5 e 6; direita: posição 7; intenção de voto: idem (3). 